\title{
PROBLEMS OF FORMATION OF THE FUTURE PRIMARY SCHOOL TEACHERS COMMUNICATIVE CREATIVITY
}

\author{
A.B. Tasova, G.Zh. Niyazova, K.M. Berkimbayev, R.E. Pralieva \\ International Kazakh-Turkish university named after H.A. Yasavi \\ B. Sattarkhanov str., 29 Turkestan, Kazakhstan, 160200
}

\begin{abstract}
The article deals with the problems of formation of communicative creativity of the future teachers primary classes. The importance of this problem is the fact that the formation of the creative principles in man in the early stages of its development determines the successful implementation of the motives that are impelling to enhance the creativity of the young generation. The analysis of this problem has allowed identifying several directions in the assessment of communicative-creative personality: the totality of creative abilities, making the process more successful; a creative approach to communication. The analysis of this problem allows to distinguish several trends in the assessment of communicative and creative personality: the totality of creative abilities, making the process more successful; a creative approach to communication. Communicative-creative of quality personality can be seen as the unity and uniqueness of cognitive, emotional and linguistic features, formed on the basis of social intelligence, which is a knowledge of the culture, social relations, customs and traditions, and manifested in the skills of communication (communicative competence) and the ability to understand relationships and people's feelings (empathy).

Training of such students is determined by the system requirements of the educational process, and the parties, included: teachers and students are welcome independence, initiative, and creative approach to business. At present, no analysis of the communicative-creativity of future primary school teachers, not identified with the components of the function, the diagnostic tools are developed. It allows to highlight the problem of how to ensure the effectiveness of development of communicative-creativity of future primary school teachers in the process of training and retraining, including the search for and scientific substantiation of methods and principles, content, forms, methods, receptions and means of development of communicative creativity in the process of higher education and their professional activities.
\end{abstract}

Key words: higher education, training future teachers of primary classes, communicative creativity

Social and economic transformations in our country set the task of formation of progressively conceiving primary school teacher able to approach critically the existing pedagogical processes, forms of the organization of training. The educational system pays a great attention to the problem of making active creative teachers familiar with receptions of the solution of non-standard tasks for real pedagogical situations. The main point of this problem that is formation of person's creative initials at early stages of his development defines successful realization of the motives which are incentive for activation of creativity of the younger generation.

The creativity in communication shown by the teacher consists of five abilities, V.A. Kan-Kalik considers: to transfer brightly and figuratively information, to understand 
a mental condition of the pupil on external manifestations, skillfully to build and develop relationship with children, skillfully to influence the partner and to interact with it, to operate the mental states, to break mental barriers and to be an optimist. The author considers the communicative tasks in front of teacher in details, structure and management of communication, barriers and a role of communicative inspiration (it is very close to understanding of creativity in communication). The emphasize is put on the opportunity and necessity of preparation for creativity of the identity of the teacher is besides emphasized [5].

It is possible to distinguish the most effective from various styles of teachers' relationship and pupils as creative. N.A. Lozhnikova defines this style as process of a flexible choice or creation of set of new ways of relationship, the most effective for achievement of the purpose in these circumstances. A product of creative style in relationship is already new situation, desirable changes in the relations of participants. From the psychological maintenance of style it is possible to note high degree of valuable and orientation unity of the teacher with the pupil, sincerity in manifestation of emotions by the tutor a moral orientation of relationship, flexibility of the teacher in use of levers on the pupil [6].

Creative pedagogical abilities can be developed, if: a) the motivation to self-improvement will be strong; b) there is profound knowledge at psychology and pedagogics; c) the constant self-critical analysis of the activity is kept. However, still the developed intuition and creative abilities are necessary, at first situations to expect result of its decision, to connect a new situation with former experience, using it partially, ability quickly and easily to present a ideas and reaction of other person, ability to take a detached view of itself and to estimate the behavior, in time to refuse installation, a template of habitual, but not suitable behavior and a way of influence, quickly to choose from many ways of the solution of a task one, the most effective, ability to achieve expedient result.

U.V. Kala undertook not only one of the first attempts of judgment of process of formation at pupils of creativity in communication (the first approach), but also conducted the only research of levels of development of the characteristic. It made the verbal test concerning manifestations of creativity of manifestations of school students in the sphere of communication, having added it with sociometry and supervision. She received close correlation connections between creative cognitive abilities (according to the test of Torrance) and manifestation of creativity in communication, close connection of creativity with erudition, existence of the higher education at parents. Probably, use of sociometric procedure for research of this phenomenon is not productive. The author considers motivation of creativity, personal features, experience and the available repertoire of behavior as the factors influencing a communication creativity. It allocated stages, a product (a new situation of communication), absence of criteria of creativity in communication, its subjective novelty. U.V. Kala defined the phenomenon as ability to modify behavior $[1 ; 2 ; 4 ; 9 ; 10 ; 15]$.

The ready state of the student of higher education institution to manifestation of creativity in professional activity is one of professional and personal new growths consisting in the condition of the identity of the student providing ability to keep creativity, a nonstandard, flexibility when performing different types of educational and professional activity $[11 ; 13]$. 
Training of such student is defined also by system of requirements imposed to educational process, and the parties included in it: both in teachers, and in pupils independence, initiative, creative approach to business are welcomed.

The modern education system has to be aimed at training future specialists not for passive accumulation of information and experience, but to form his requirement and ability to think, and to think independently and creatively; and special relevance is gained by development of the abilities allowing to find optimum solutions at uncertainty of conditions and diversity of answers [12; 16; 17].

In this regard new and especially important tasks one of which is the education and training promoting full development of the personality, her creative aspirations, adaptation of the person to various environment, dynamically changing social and economic situation are set for education. To achieve this objective, it is necessary to have the teacher possessed all above-named characteristics of the creative person. In this regard as an applied task for pedagogical psychology there is a question of formation of creative abilities in pedagogical activity, communicative creativity of the teacher.

There is a number of the researches devoted to separate aspects of a phenomenon of creativity: intellectual creativity (E. Torrance, E.E. Tunik, M.A. Holodnaya, etc.) [9; 10]; social creativity (N.A. Manevich, E.Yu. Chichuk); emotional creativity (I.N. Andreyeva, T.N. Berezin, R.N. Tereshchenko) [1; 2], etc. Works of school of O.V. Lesher, the researching problems of cross-cultural communication and communicative creativity are devoted to communicative creativity [7]. The interrelation of intuition and logic in creativity was defined by R.M. Granovskaya, Ya.A. Ponomarev, P.V. Simonov [3], etc.; motivator of communicative creativity was considered by A. Maslou, K. Rogers [8].

Despite a these number of scientific researches on this problem, communicative creativity of future primary school teachers remains insufficiently studied phenomenon.

In this plan statement of a question of training communicatively creative primary school teachers at the modern higher school is represented quite reasonable.

The analysis allowed to allocate some directions at an assessment of the communicative and creative personality: the set of creative abilities doing process by more successful; creative relation to communication. Communicative and creative qualities of the personality can be considered as unity and an originality of the cognitive, emotional and linguistic features which are formed on the basis of social intelligence, presenting knowledge of culture, the social relations, traditions both traditions, and shown in communication skills (communicative competence) and in ability to understand the relations and feelings of people (empathy).

Communicative creativity is ability to adapt fot optimization of own communicative behavior in relation to the changing situations of communication and activity (E.V. Tsukanova). It is found mainly in three main spheres:

1) contextual characteristics of communication (approach of a communicative context to a business subject if in general communication is directed on the organization and realization of joint activity);

2) functional orientation of communication (contact maintenance, interaction coordination, mutual correction of actions, exchange of information, redistribution of functions); 
3) operational methods of interaction (temporary organization of communicative process, updating means and ways of communication).

Main characteristics of communicative creativity: easily creation of numerous behavior options of individual, flexibility in change by the subject of reaction tactics, use of various receptions of behavior, originality which was shown in creation of non-standard ways of the solution of situations of problem character. Communication the creative activity meaning development of creativity in the course of communication. In the organization of creative communicative activity important reference points are the communication purposes: establishment of contacts between participants of dialogue; exchange of messages, opinions, plans, decisions; motivation of the activity of the partner in communication directed on performance of mutually advantageous actions; coordination - coordination of the organization of joint activity; understanding of sense of intentions, installations of the partner in communication; influence on emotions, intentions, decisions, opinions; establishment of the relations in system of business communication; belief and partner's overpersuasion; resolution of conflicts [14].

Communicative creativity of future elementary school teacher is presented by system of the properties and abilities providing possibility of the non-standard, creative solution of a pedagogical situation and is shown in a readiness to generate various original ideas in the conditions of professional communication.

Until now there is no analysis of communicative creativity of future elementary school teachers; components, functions are not defined, the diagnostic tools are not developed. All this demands the solution of the following contradictions:

- at the social and pedagogical level - between the high public importance of communicative creativity development in future primary school teachers and insufficient attention to the solution of this question in system of the higher education;

- at the scientific-theoretical level - between need of theoretical justification of future primary school teachers' communicative creativity development and an insufficient readiness of this aspect of vocational training;

- at the scientific and methodical level - between the high potential of educational process in future primary school teachers' communicative creativity development and an insufficient readiness of educational and methodical ensuring the studied process.

These contradictions allow to allocate a problem how to provide the efficiency of developing communicative creativity of future primary school teachers in the course of their preparation and retraining including search and scientific justification of approaches and the principles, contents, forms, methods, receptions and development tools of communicative creativity in the course of high school education and their professional activity.

Thus, the specification of scientific ideas of the maintenance of communicative creativity of future primary school teachers, development of its diagnostics, identification of the corresponding pedagogical conditions and design of effective technology of their creation is required. All this will promote assimilation of fundamental components of professional creativity - an important component in system of training of future elementary school teachers, the phenomena of the versatile and demanding studying of both internal, and external aspects of differences in communication. 


\section{LITERATURE}

[1] Андреева И.Н. Эмоциональная креативность и ее отличия от эмоционального интеллекта // Віснік Чернігівського державного педагогічного універсітету імені Т.Г. Шевченка. Випуск 41. Серія: Псіхологічні науки. 2006. Т. 1. С. 13-15.

[2] Березина T.Н. Интеллектуальные и творческие способности человека. М.: РИЦ МГГУ им. М.А. Шолохова, 2009. 320 с.

[3] Грановская Р.М., Крижанская Ю.С. Воздействие установки на восприятие информации в активных способах обучения // Методика и практика преподавания в техническом вузе: науч.-метод. сб. ст. Л.: ЛПИ, 1985. С. 14-21.

[4] Кала У.В. Формирование у старшеклассников творческого отношения к общению: дисс.... канд. пед. наук. Тарту, 1982. 281 с.

[5] Кан-Калик B.A. Грамматика общения. М.: Росредагентство, 1995. 108 с.

[6] Ложникова А.Н. Психолого-педагогические основы сотрудничества педагогов и школьников в учебно-воспитательном процессе. Кемерово: КемГУ, 1994. 173 с.

[7] Сарапулова A.B. Развитие коммуникативной креативности студентов технического вуза в процессе межкультурной коммуникации: дисс. ... канд. пед. наук. Магнитогорск, 2014. $230 \mathrm{c}$.

[8] Роджерс K. Взгляд на психотерапию. Становление человека. М.: Дайджест, 1994. 425 с.

[9] Туник E.Е. Опросник креативности Джонсона. СПб.: Питер Пресс, 1997. 608 с.

[10] Холодная М.A. Психология интеллекта: парадигмы исследования. Томск: Барс, 1997. 392 с.

[11] Цуканова E.B. Деструктивные параметры взаимодействия в ситуации временного дефицита. М.: Наука, 1985. 344 с.

[12] Bekbolatova I.U., Berkimbaev K.M., Atemova K.T. Development of personal and professional potential // European Science and Technology: materials of the VII internationalresearch and practice conference. Vol. II. Munich. April 23th - 24th, 2014 / publishing officeVela VerlagWaldkraiburg - Munich - Germany, 2014. 624 p.

[13] Zhelezovskaja G.I., Abramova, N.In. Gudkova E.N. Communicative system of the culture of speech communication // problems of modern education: materials of IV International scientific-practical conference. Prague: Vedecco vydavatelske centrum - Sociosfera-CZ, 2013. C. 97-100.

[14] Niyazova G., Bekbulatova I., Kerimbaeva B., Abdullina G. The methodology of the formation of the communicativeorientation of the "English" course by means ofinformation and telecommunication technologies (itt) in the institutions of higher education. Journal of Language and Literature, Vol. 6. No. 4. November, 2015 Pp. 351-354.

[15] Torrance E.P. Education and creative potential. Minneapolis, 1963.

[16] Uzakbaeva S.A., Niyazova G.Zh., Berdi D.K., Seydakhmetov E.E., Baimukhanbetov B.M. The introduction of interactive methods of training of forming of the future teachers // Global Journal on Technology. Vol. 4 (2013): 3rd World Conference on Innovation and Computer Science (INSODE-2013) 26-28.04.2013. Antalya, Turkey.

[17] Zoldasbekova S.A., Bayzakhova S.Sh., Berkimbaev K.M., Niyazoav G., Saparbekova G.A., Bimaganbetova A.K. Formation of professional competence of a future teacher as a condition of developing creative abilities of pupils // Jokull journal. Vol. 64. No. 6. June 2014. Pp. 43-48.

(C) Tasova A.B., Niyazova G.Zh., Berkimbayev K.M., Pralieva R.E., 2018

\section{Article history:}

Received: 22 January, 2018

Accepted: 28 February, 2018

For citation:

Tasova A.B., Niyazova G.Zh., Berkimbayev K.M., Pralieva R.E. (2018). Problems of formation of the future primary school teachers communicative creativity. RUDN Journal of Informatization Education, 15 (2), 182-189. DOI 10.22363/2312-8631-2018-15-2-182-189 


\title{
Bio Note:
}

Tasova Assel Baimurzaeva, graduate student of International Kazakh-Turkish University named after H.A. Yasavi. Contact information: e-mail: asel.tasova@mail.ru

Niyazova Gulzhan Zholaushievna, candidate of pedagogical sciences, associate professor, head of the chair of computer science of International Kazakh-Turkish University named after H.A. Yasavi. Contact information: e-mail: ngulzhan@bk.ru

Berkimbaev Kamalbek Meirbekobich, doctor of pedagogical sciences, full professor, director of the Kentau Institute of International Kazakh-Turkish University named after H.A. Yasavi. Contact information: e-mail: kamalbek.berkimbaev@yandex.kz

Pralieva Rabiga Esimova, senior lecturer at International Kazakh-Turkish University named after H.A. Yasavi. Contact information: e-mail: kamalbey@mail.ru

\section{ПРОБЛЕМЫ ФОРМИРОВАНИЯ КОММУНИКАТИВНОЙ КРЕАТИВНОСТИ У БУДУЩИХ УЧИТЕЛЕЙ НАЧАЛЬНЫХ КЛАССОВ}

\author{
А.Б. Тасова, Г.Ж. Ниязова, К.М. Беркимбаев, Р.Е. Пралиева \\ Международный казахско-турецкий университет им. Х.А. Ясави \\ ул. Б. Саттарханова, 29, Туркестан, Республика Казахстан, 160200
}

\begin{abstract}
В статье обсуждается проблемы формирования коммуникативной креативности у будущих учителей начальных классов. Суть данной проблемы состоит в том, что формирование творческих начал в человеке на ранних этапах его развития определяет успешную реализацию мотивов, являющихся побудительными для активизации творчества молодого поколения. Анализ данной проблемы позволил выделить несколько направлений при оценке коммуникативно-креативной личности: совокупность творческих способностей, делающая процесс более успешным; творческое отношение к общению. Коммуникативно-креативные качества личности можно рассматривать как единство и своеобразие когнитивных, эмоциональных и лингвистических особенностей, формирующихся на основе социального интеллекта, представляющего собой знания о культуре, социальных отношениях, обычаях и традициях, и проявляющихся в умениях и навыках общения (коммуникативной компетентности) и в умении понимать отношения и чувства людей (эмпатии). Подготовка такого студента определяется и системой требований, предъявляемых к образовательному процессу, и сторонам, включенным в него: и в педагогах, и в учащихся приветствуются самостоятельность, инициативность, творческий подход к делу. В настоящее время пока отсутствует анализ коммуникативной креативности будущих учителей начальных классов, не определены ее компоненты, функции, не разработан диагностический инструментарий. Это позволяют выделить проблему, как обеспечить эффективность развития коммуникативной креативности будущих учителей начальных классов в процессе их подготовки и переподготовки, включающую поиск и научное обоснование подходов и принципов, содержания, форм, методов, приемов и средств развития коммуникативной креативности в процессе вузовского образования и их профессиональной деятельности.
\end{abstract}

Ключевые слова: высшая образование, подготовка будущих учителей начальных классов, коммуникативная креативность 


\section{REFERENCES}

[1] Andreeva I.N. Jemocional'naja kreativnost' i ejo otlichija ot jemocional'nogo intellekta [Emotional creativity and its differences from emotional intelligence]. Vistnik Chernigivs'kogo derzhavnogo pedagogichnogo universitetu imeni T.G. Shevchenka. Serija: Psihologichni nauki [Bulletin of the Chernihiv state pedagogical University named after T.G. Shevchenko. "Pschology science" series:]. 2006. No. 41. Vol. 1. Pp. 13-15.

[2] Berezina T.N. Intellektual'nye i tvorcheskie sposobnosti cheloveka [Intellectual and creative abilities of man]. M.: RIC MGGU im. M.A. Sholohova, 2009. 320 p.

[3] Granovskaja R.M., Krizhanskaja Ju.S. Vozdejstvie ustanovki na vosprijatie informacii v aktivnyh sposobah obuchenija [The influence of the installation on the perception of information in active learning methods]. Metodika i praktika prepodavanija v tehnicheskom vuze [Methods and practice of teaching in a technical university]: nauchno-metodicheskij sb. statej. L.: LPI, 1985. Pp. 1421.

[4] Kala U.V. Formirovanie u starsheklassnikov tvorcheskogo otnoshenija $k$ obshheniju [Formation at seniors pupils' creative relation to communication]: diss. ... kand. ped. nauk. Tartu, 1982. $281 \mathrm{p}$.

[5] Kan-Kalik V.A. Grammatika obshhenija [Grammar communication]. M.: Rosredagentstvo, 1995. $108 \mathrm{p}$.

[6] Lozhnikova A.N. Psihologo-pedagogicheskie osnovy sotrudnichestva pedagogov $i$ shkol'nikov v uchebno-vospitatel'nom processe [Psychology and pedagogical bases of cooperation of teachers and school students]. Kemerovo: KemGU, 1994. 173 p.

[7] Sarapulova A.V. Razvitie kommunikativnoj kreativnosti studentov tehnicheskogo vuza v processe mezhkul'turnoj kommunikacii [The development of communicative creativity of students of technical universities in the process of intercultural communication]: diss. ... kand. ped. nauk. Magnitogorsk, 2014. $230 \mathrm{p}$.

[8] Rodzhers K. Vzgljad na psihoterapiju. Stanovlenie cheloveka [Perspective on psychotherapy. The development of man]. M.: Dajdzhest, 1994. 425 p.

[9] Tunik E.E. Oprosnik kreativnosti Dzhonsona [Questionnaire of creativity Johnson]. SPb.: Piter Press, 1997. 608 p.

[10] Holodnaja M.A. Psihologija intellekta:paradigmy issledovanija [Psychology of intelligence: research paradigm]. Tomsk: Bars, 1997. $392 \mathrm{p}$.

[11] Cukanova E.V. Destruktivnye parametry vzaimodejstvija v situacii vremennogo deficit [Destructive interaction parameters in a situation of a temporary shortfall]. M.: Nauka, 1985. 344 p.

[12] Bekbolatova I.U., Berkimbaev K.M., Atemova K.T. Development of personal and professional potential // European Science and Technology: materials of the VII internationalresearch and practice conference. Vol. II. Munich. April 23th - 24th, 2014 / publishing officeVela VerlagWaldkraiburg - Munich - Germany, 2014. 624 p.

[13] Zhelezovskaja G.I., Abramova, N.In. Gudkova E.N. Communicative system of the culture of speech communication // problems of modern education: materials of IV International scientificpractical conference. Prague: Vedecco vydavatelske centrum - Sociosfera-CZ, 2013. C. 97-100.

[14] Niyazova G., Bekbulatova I., Kerimbaeva B., Abdullina G. The methodology of the formation of the communicativeorientation of the "English" course by means ofinformation and telecommunication technologies (itt) in the institutions of higher education. Journal of Language and Literature. Vol. 6. No. 4. November, 2015. Pp. 351-354.

[15] Torrance E.P. Education and creative potential. Minneapolis, 1963.

[16] Uzakbaeva S.A., Niyazova G.Zh., Berdi D.K., Seydakhmetov E.E., Baimukhanbetov B.M. The introduction of interactive methods of training of forming of the future teachers // Global Journal on Technology. Vol. 4 (2013): 3rd World Conference on Innovation and Computer Science (INSODE-2013) 26-28.04.2013. Antalya, Turkey.

[17] Zoldasbekova S.A., Bayzakhova S.Sh., Berkimbaev K.M., Niyazoav G., Saparbekova G.A., Bimaganbetova A.K. Formation of professional competence of a future teacher as a condition of developing creative abilities of pupils // Jokull journal. Vol. 64. No. 6. June 2014. Pp. 43-48. 


\section{История статьи:}

Дата поступления в редакцию: 22 января 2018

Дата принятия к печати: 28 февраля 2018

\section{Для цитирования:}

Тасова А.Б., Ниязова Г.Ж., Беркимбаев К.М., Пралиева Р.Е. Проблемы формирования коммуникативной креативности у будущих учителей начальных классов // Вестник Российского университета дружбы народов. Серия «Информатизация образования». 2018. Т. 15. № 2. C. 182-189. DOI 10.22363/2312-8631-2018-15-2-182-189

\section{Сведения об авторах:}

Тасова Асель Баймурзаевна, докторант Международного казахско-турецкого университета им. Х.А. Ясави. Контактная информация: e-mail: asel.tasova@mail.ru

Ниязова Гулэкан Жолаушиевна, кандидат педагогических наук, доцент, заведующая кафедрой компьютерных наук Международного казахско-турецкого университета им. Х.А. Ясави. Контактная информация: e-mail: ngulzhan@bk.ru

Беркимбаев Камалбек Меирбекович, доктор педагогических наук, профессор, директор Кентауского института Международного казахско-турецкого университета им. Х.А. Ясави. Контактная информация: e-mail: kamalbek.berkimbaev@yandex.kz

Пралиева Рабига Есимовна, старший преподаватель Международного казахско-турецкого университета им. Х.А. Ясави. Контактная информация: e-mail: kamalbey@mail.ru 